\title{
Analisis Kualitas Pelayanan P.T. Kereta Api Indonesia terhadap Tingkat Kepuasan Pengguna Jasa pada Stasiun Cepu
}

\author{
Balla Wahyu Budiarto, email : balla@ppi.ac.id \\ Sigit Priyanto, email : spriyanto2007@ugm.ac.id \\ Imam Muthohar, email : imam.muthohar@ugm.ac.id \\ Magister Sistem dan Teknik Transportasi, Departemen Teknik Sipil dan Lingkungan, Universitas \\ Gadjah Mada, Yogyakarta
}

\begin{abstract}
ABSTRAK
Stasiun Cepu dianggap masih belum optimal dalam memberikan pelayanan terhadap pelanggan karena masih jauh dari harapan dan masih banyak para pelanggan yang mengeluhkan mengenai fasilitas pelayanan yang disediakan. Tujuan penelitian ini untuk memberikan rekomendasi perbaikan prioritas utama tingkat kepuasaan pengguna jasa kepada penyedia jasa PT. KAI terhadap peningkatan pelayanan di Stasiun Cepu yang mengacu pada Standar Pelayanan Minimal (SPM) di stasiun yang terdapat dalam PM 63 tahun 2019 tentang Standar Pelayanan Minimum Untuk Angkutan Orang Dengan Kereta Api. Penelitian ini menggunakan tipe penelitian deskriptif kuantitatif. Sasaran penelitian ini untuk mengetahui nilai CSI, IPA dan penghitungan Indeks PGCV yang berguna untuk membantu metode IPA dalam perbaikan atribut. Hasil dari penelitian ini didapatkan nilai CSI sebesar $74 \%$ yaitu dengan predikat puas, hasil dari IPA yang menjadi prioritas untuk ditingkatkan kualitas ada di kuadran I dan kuadran III dan dengan metode PGCV prioritas perbaikan atribut kualitas layanan yang harus segara diperbaiki berada di kuadran I terdapat 2 atribut yaitu kebersihan stasiun, kebersihan dan kenyamanan toilet.
\end{abstract}

Kata Kunci : kualitas pelayanan, tingkat kepuasan, Customer Satisfaction Indeks, Importance Performance Analysis, Potential Gain in Customer Value

\section{ABSTRACT}

Cepu Station is considered still not optimal in providing services to customers because it is still far from expectations and there are still many customers who complain about the service facilities provided. The purpose of this study is to provide recommendations for improvement of the main priority level of service user satisfaction to service providers PT. KAI towards improving services at Cepu Station which refers to the Minimum Service Standards (SPM) at stations contained in PM 63 of 2019 concerning Minimum Service Standards for Transportation of People by Train. This study uses a quantitative descriptive research type. The target of this research is to know the value of CSI, IPA and the calculation of the PGCV Index which is useful for assisting the IPA method in attribute improvement. The results of this study obtained a CSI value of 74\%, namely with the predicate of being satisfied, the results of the IPA which became a priority to improve the quality of quadrant I and quadrant III and with the PGCV method the priority of improving service quality attributes that must be immediately repaired was in quadrant I there were 2 attributes namely station cleanliness, toilet cleanliness and comfort.

Keywords: service quality, satisfaction level, Customer Satisfaction Index, Importance Performance Analysis, Potential Gain in Customer Value

\section{PENDAHULUAN}

\subsection{Latar Belakang}

Corona virus merupakan keluarga besar virus yang menyebabkan penyakit pada manusia dan hewan. Pada manusia biasanya menyebabkan penyakit infeksi saluran pernapasan, mulai flu biasa hingga penyakit yang serius seperti Middle East
Respiratory Syndrome (MERS) dan Sindrom Pernafasan Akut Berat/ Severe Acute Respiratory Syndrome (SARS) ( (Kemenkes, 2020). Jumlah penderita Covid-19 semakin meningkat secara terus menerus. Beberapa peneliti mengemukakan dampak Covid-19 terhadap berbagai sektor akibat pembatasan pergerakan orang, antara lain terjadi penurunan penumpang. PT. Kereta Api Indonesia (PT. KAI) adalah Badan Usaha Milik Negara 
(BUMN) yang menyelenggarakan pelayanan jasa angkutan kereta api.

Penelitian ini diambil berdasarkan bahan analisis diatas sehingga didapatkan penelitian tentang pelayanan di stasiun yang mengacu pada Standar Pelayanan Minimal (SPM) di stasiun yang terdapat dalam Peraturan Menteri Perhubungan RI No. PM 63 tahun 2019 Tentang Standar Pelayanan Minimum Angkutan Orang dengan Kereta Api, 2019 tentang Standar Pelayanan Minimum Untuk Angkutan Orang Dengan Kereta Api dan hasil pengamatan. Stasiun Cepu dianggap masih belum optimal dalam memberikan pelayanan terhadap pelanggan karena masih jauh dari harapan yang ada. Masih banyak kekurangan yang terjadi pada pelayanan Stasiun Cepu. Kekurangan yang masih dirasakan yaitu fasilitas ruang tunggu dan tempat duduk. Seharusnya berdasarkan SPM yang berlaku yaitu fasilitas ruang tunggu dan tempat duduk tersedia di stasiun harus cukup untuk menampung pelanggan yang akan berpergian dengan kereta api melalui Stasiun Cepu, akan tetapi masih banyak para pelanggan yang mengeluhkan mengenai fasilitas pelayanan ruang tunggu dan tempat duduk yang tersedia.

Permasalahan juga terdapat pada pelayanan fasilitas toilet, fasilitas toilet yang ada pada stasiun minimalnya tersedia toilet pria dan wanita dengan persyaratan toilet pria (4 urinoir, $3 \mathrm{wc}, 2$ wastafel) dan toilet wanita (6 wc, 2 wastafel) tetapi menurut data yang dimiliki Stasiun Cepu, toilet yang tersedia di stasiun Cepu pada toilet pria ( 3 urinoir, $3 \mathrm{wc}, 1$ wastafel) dan pada toilet wanita ( $3 \mathrm{wc}, 3$ wastafel ) 3 wc itu terdiri dari 1 closed jongkok, 1 closed disabilitas, 1 closed duduk, wastafel dan kamar mandi terlihat berkerak sehingga pengguna jasa merasa tidak nyaman. Penelitian ini menggunakan tipe penelitian deskriptif kuantitatif. Dalam penelitian ini hanya ingin mengetahui tingkat kepuasan pengguna jasa PT. Kereta Api Indonesia di Stasiun Cepu. Metode kuantitatif ini menjelaskan atau menguraikan data yang diperoleh dari lapangan dan dari hasil perhitungan dengan menggunakan Importance and Performance Analysis dan Potential Gain In Customer Value (PGCV) atau analisis tingkat kepentingan dan kinerja kepuasan pengguna jasa untuk mengetahui tingkat kepuasan pengguna jasa (Aritonang, 2005). Berdasarkan dari permasalahan tersebut diatas, dapat dilakukan penelitian dengan judul "Analisis Kualitas Pelayanan PT. Kereta Api Indonesia Terhadap Tingkat Kepuasan Pengguna Jasa Pada Stasiun Cepu".

\subsection{Pertanyaan Penelitian}

Pertanyaan penelitian sebagai berikut:

1. Bagaimanakah karakteristik pengguna jasa Stasiun Cepu?

2. Bagaimana nilai customer satisfaction index (CSI) melalui perhitungan nilai kinerja dan tingkat kepentingan pengguna jasa terhadap pelayanan di Stasiun Cepu dengan metode IPA ?

3. Bagaimana mengidentifikasi dimensi kualitas pelayanan yang mempengaruhi kepuasan pengguna jasa dengan metode Importance Performance Analysis (IPA) dan metode Potential Gain in Customer Value (PGCV)?

4. Bagaimana indikator pelayanan di Stasiun Cepu yang perlu mendapat prioritas utama untuk ditingkatkan dengan metode IPA dan PGCV ?

\subsection{Tujuan Penelitian}

Tujuan penelitian ini adalah sebagai berikut .

1. Mengetahui karakteristik pengguna jasa Stasiun Cepu.

2. Mengetahui nilai customer satisfaction index (CSI) melalui perhitungan nilai kinerja dan tingkat kepentingan pengguna jasa terhadap pelayanan di Stasiun Cepu dengan metode IPA.

3. Untuk mengidentifikasi dimensi kualitas pelayanan menggunakan metode IPA (Important Performance Analisys) dan metode PGCV (potential gain customer value).

4. Memberikan rekomendasi usulan perbaikan prioritas utama tingkat kepuasaan pengguna jasa kepada penyedia jasa PT. KAI terhadap peningkatan pelayanan dan fasilitas di Stasiun Cepu.

\subsection{Keaslian Penelitian}

Penelitian yang dilakukan oleh Heiscmidt (2013) dengan metode IPA dengan sasaran sebuah perusahan dan hasil yang diperoleh adalah kenyamanan lokasi dan jam operasional menjadi faktor dasar. Sedangkan penelitian yang dilakukan oleh Iriani (2018) di sebuah rumah sakit dengan metode IPA dan PGCV didapatkan hasil atribut yang harus segera diperbaiki dan menyebabkan ketidak puasan pasien adalah karyawan selalu melakukan 3S. Penelitian yang dilakukan oleh Wahyu (2020) dengan metode multiple regresi linier di perusahaan Kereta Api Indonesia dengan hasil Perusahaan Kereta Api Indonesia telah melakukan peran sangat baik dalam mengatasi masalah dampak pandemik Covid-19 bagi pengguna jasa Perusahaan Kereta Api Indonesia. 
Penelitian yang dilakukan sebelumnya terdapat perbedaan, penelitian ini dilakukan menggunakan analisis teknis yang mengacu pada PM Perhubungan No. 63 Tahun 2019 tentang SPM untuk Angkutan Orang dengan Kereta Api dengan menggunakan metode Customer Satisfaction Indeks (CSI) yaitu melalui perhitungan nilai kinerja dan tingkat kepentingan pengguna jasa terhadap pelayanan di Stasiun Cepu, dengan menggunakan metode IPA (Important Performance Analisys) dan metode PGCV (Potential Gain Customer Value) dan lokasi penelitian ini adalah di Stasiun Cepu.

\section{TINJAUAN PUSTAKA}

\subsection{Kepuasan Pelanggan Pengguna Jasa Layanan Transportasi}

Kepuasan pelanggan merupakan evaluasi spesifik terhadap keseluruhan pelayanan yang diberikan pemberi jasa (Astuti, 2007), sehingga kepuasan pelanggan hanya dapat dinilai berdasarkan pengalaman yang pernah dialami saat proses pemberian pelayanan, kepuasan pelanggan terutama dibidang jasa menjadi keharusan agar perusahaan tetap sukses.

Kepuasan pelanggan angkutan kereta api dibagi menjadi dua komponen yaitu kepuasan terhadap pelayanan stasiun kereta api dan kepuasan terhadap pelayanan selama perjalanan dengan beberapa faktor yang menjadi bahan analisis sebagai berikut (Eurobarometer, 2013)

a. Kepuasan terhadap pelayanan di stasiun (informasi perjalanan, kemudahan mendapatkan tiket, adanya mekanisme pengaduan/ keluhan pengguna, kebersihan dan pemeliharaan).

b. Kepuasan terhadap pelayanan di perjalanan (frekuensi kereta, ketepatan waktu dan keandalan, ketersediaan tiket terusan, ketersediaan informasi perjalanan, petugas pelayanan di kereta, kebersihan, akses ke stasiun).

Dalam Undang-Undang Republik Indonesia Nomor 23 Tahun 2007 tentang Perkeretaapian, dijelaskan bahwa pengertian dari pengguna jasa merupakan setiap orang dan/atau badan hukum yang menggunakan jasa angkutan kereta api, baik untuk angkutan orang maupun barang. Di situasi pandemi sekarang ini pengendalian kapasitas penumpang/pengguna jasa untuk semua prasarana dan sarana perkeretaapian harus memenuhi protokol kesehatan diatur secara bertahap sesuai dengan Surat Edaran Nomor : SE 14 Tahun 2020 Tentang Pedoman dan Petunjuk Teknis Pengendalian Transportasi Perkeretaapian dalam Masa Adaptasi Kebiasaan Baru Untuk Mencegah Penyebaran Corona Virus Disease 2019 (Covid-19) sehingga pengguna jasa kereta api mengalami banyak penurunan.

\subsection{Pelayanan Publik}

Pelayanan publik diartikan, pemberian layanan (melayani) keperluan orang atau masyarakat yang mempunyai kepentingan pada organisasi itu sesuai dengan aturan pokok dan tata cara yang telah ditetapkan. Selanjutnya menurut Keputusan Menteri Pendayagunaan Aparatur Negara (Menpan) Nomor 63 Tahun 2004 tentang Pedoman Umum Penyelenggaraan Pelayanan Publik, pelayanan publik adalah segala kegiatan pelayanan yang dilaksanakan oleh penyelenggara pelayanan publik sebagai upaya pemenuhan kebutuhan penerima pelayanan maupun pelaksanaan ketentuan peraturan perundang-undangan.

Berdasarkan Keputusan Menpan Nomor 63 Tahun 2003 disebutkan bahwa penyelenggaraan pelayanan harus memenuhi beberapa prinsip sebagai berikut:

1. Kesederhanaan.

2. Kejelasan.

3. Kepastian waktu.

4. Akurasi.

5. Keamanan.

6. Tanggung jawab.

7. Kelengkapan sarana dan prasarana.

8. Kemudahan akses

9. Kedisiplinan, kesopanan dan keramahan.

10. Kenyamanan.

\subsection{Tinjauan tentang Kepuasan}

Menurut (Tjiptono, 1998) menyatakan bahwa kepuasan pelanggan dapat menciptakan kesetiaan dan loyalitas pelanggan kepada perusahaan.

Faktor - faktor yang mempengaruhi persepsi dan harapan konsumen dalam kepuasan pelanggan (Gasperz, 1997) antara lain :

a. Kebutuhan dan keinginan yang berkaitan dengan hal-hal yang dirasakan konsumen ketika sedang mencoba melakukan transaksi dengan produsen produk.

b. Pengalaman masa lalu ketika mengkonsumsi produk dari perusahaan maupun pesaing pesaingnya. 
c. Pengalaman dari teman - teman.

\section{LANDASAN TEORI}

\subsection{Metode Importance Performance Analysis (IPA)}

Teknik (Importance Performance Analysis) IPA dilakukan dimana responden diminta untuk meranking berbagai elemen (atribut) dari penawaran berdasarkan derajat pentingnya setiap elemen dan seberapa baik kinerja perusahaan dalam masing-masing elemen (importance performance ratings). Teknik ini dikenal pula dengan istilah Importance Performance Analysis (James, 1977). Diagram kartesius Importance Performance Analysis merupakan suatu diagram yang dibagi menjadi 4 (empat) bagian dan dibatasi oleh 2 (dua) buah garis yang berpotongan tegak lurus pada titik $(\mathrm{x}, \mathrm{y})$, dimana $\mathrm{x}$ merupakan rata-rata dari rata-rata skor penilaian kinerja, sedangkan y merupakan ratarata dari skor kepentingan pengguna jasa.

Skor penilaian terhadap kinerja (Variabel X) dan kepentingan (Variabel Y) menggunakan skala likert di mana pelanggan sebagai responden diminta untuk menentukan tingkat kepentingan dan tingkat kinerja pada atribut - atribut yang ditanyakan. Rumus yang digunakan dalam penentuannya adalah Persamaan (1).

$$
\overline{\mathrm{X}} i=\frac{\Sigma X i}{n} \text { dan } \overline{\mathrm{Y}} i=\frac{\Sigma Y i}{n}
$$

Dimana

$$
\begin{array}{ll}
\overline{\mathrm{X}} \mathrm{i} & =\text { Skor rata }- \text { rata tingkat persepsi kerja } \\
\overline{\mathrm{Y}} \mathrm{i} & =\text { Skor rata }- \text { rata tingkat persepsi kepentingan } \\
\mathrm{Xi} & =\text { Total skor tingkat persepsi kinerja } \\
\mathrm{Yi} & =\text { Total skor tingkat kepentingan } \\
\mathrm{n} & =\text { Jumlah responden }
\end{array}
$$

\subsection{Potential Gain In Customer Value (PGCV)}

Potential Gain In Customer Value ini dipakai untuk menentukan prioritas perbaikan yang harus dilakukan oleh perusahaan. Analisis dari Importance Performance Analysis kurang dapat merekomendasikan perbaikan yang menjadi prioritas utama. Karena itu dipergunakan alat analisis yang lain yaitu analisis melalui angka indeks PGCV.

Indeks PGCV ini dapat menganalisis masingmasing atribut yang diteliti. Kelebihan inilah yang dapat digunakan untuk melengkapi analisis IPA dimana metode tersebut hanya membagi atribut ke dalam bagian yang perlu prioritas perbaikan atau tidak (Hom, 1997).

Berikut adalah langkah-langkah menghitung Potential Gain in Cutomer Value (PGCV) :

1. Menghitung nilai Achieved Customer Value (ACV) dapat dilihat pada Persamaan (2)

$$
\mathrm{ACV}=\mathrm{I} \times \mathrm{P}
$$

Keterangan:

$$
\begin{array}{ll}
\mathrm{ACV} & =\text { nilai pencapaian konsumen } \\
\mathrm{I} & =\text { nilai rata-rata untuk ekspektasi } \\
\mathrm{P} & =\text { nilai rata-rata untuk kinerja }
\end{array}
$$

2. Menghitung Ultimate Desired Customer Value (UDCV) dapat dilihat pada Persamaan (3).

Keterangan:

$$
\mathrm{UDCV}=\mathrm{I} \times \mathrm{Ps}
$$

$\mathrm{UDCV}=$ Nilai akhir keinginan konsumen

I =Nilai rata-rata untuk ekspektasi

Ps =Nilai kinerja maksimum dalam skala likert yang dipilih

3. Menghitung index PGCV dapat dilihat pada Persamaan (4).

$$
\mathrm{PGCV}=\mathrm{UDCV}-\mathrm{ACV}
$$

Bila suatu item mendapatkan nilai indeks PGCV terbesar, maka item tersebut mendapatkan prioritas utama untuk diperbaiki kinerjanya baru menyusul item kedua dan seterusnya.

\subsection{Metode Customer Satisfaction Index (CSI)}

Indeks kepuasan konsumen atau Customer Satisfaction Index (CSI) sangat berguna untuk tujuan internal perusahaan, contohnya adalah memantau perbaikan pelayanan, memotivasi karyawan maupun pemberian bonus sebagai gambaran yang mewakili tingkat kepuasan menyeluruh pelanggan.

Model pengukuran kepuasan pelanggan adalah model sebab-akibat dengan indeks untuk penggerak kepuasan di sisi kiri (ekspektasi pelanggan, kualitas yang dirasakan, dan nilai yang dipersepsikan), kepuasan di tengah, dan hasil dari kepuasan di sisi kanan ( keluhan pelanggan dan loyalitas pelanggan, termasuk retensi pelanggan dan toleransi harga) (Fornell, 1996). 
Untuk mengetahui besarnya CSI, maka dapat dilakukan langkah - langkah sebagai berikut (Aritonang, 2005) :

a. Menentukan Mean Importance Score (MIS) tiap - tiap variabel.

b. Membuat Weight factors (WF) per variabel. Bobot ini merupakan persentase MIS per variabel terhadap total MIS seluruh variabel.

c. Menentukan Mean Satisfaction Score (MSS) tiap atribut.

d. Membuat Weight Score (WS) tiap variabel. Bobot ini merupakan perkalian antara WF dengan MSS

e. Menentukan Customer Satisfaction Index (CSI)

CSI merupakan indeks untuk menentukan tingkat kepuasan pelanggan secara menyeluruh dengan pendekatan yang mempertimbangkan tingkat kepentingan dari atribut-atribut yang diukur. Penghitungan Customer Satisfaction Index (CSI) dapat dilihat pada Persamaan (5).

\section{Dimana :}

$$
\mathrm{CSI}=\frac{\sum_{k-1}^{p} W S}{H S}
$$

HS : $($ Highest Scale $)$ = Skala maksimum yang digunakan.

\subsection{Pengambilan Sampel}

Pada penelitian ini teknik yang digunakan untuk menentukan sampel adalah dengan cara probability sampling dengan metode random sampling dengan metode ini pengambilan sampel dari populasi dilakukan secara acak sehingga setiap orang mempunyai kesempatan yang sama. Metode ini memiliki prosedur pemilihan sampling yang dilakukan dengan pertimbangan subjektif tertentu berdasar beberapa ciri/karateristik yang dimiliki oleh sampel tersebut.

Penentuan jumlah minimum sampel pada penelitian ini menggunakan rumus Slovin (Umar, 1998), dengan menggunakan Persamaan (6).

$$
n=\frac{N}{\left(1+N e^{2}\right)}
$$

$$
\begin{aligned}
& \text { Dimana : } \quad=\frac{30393}{1+30393(0,1)^{2}}=99,67 \\
& n \quad=\text { Jumlah sampel } \\
& \mathrm{N} \quad=\text { Populasi } \\
& \mathrm{e} \quad=\text { Sampling error }
\end{aligned}
$$

Jumlah sampel yang didapatkan 99,67 dibulatkan 100 orang. Penelitian ini memperoleh sampel 132 orang.

\section{METODE PENELITIAN}

\subsection{Desain Penelitian}

Penelitian ini menggunakan tipe penelitian deskriptif kuantitatif. Penelitian deskriptif adalah penelitian yang dilakukan untuk mengetahui nilai variabel mandiri, baik satu variabel atau lebih (independen) tanpa membuat perbandingan, atau menghubungkan dengan variabel lain. Dalam penelitian ini hanya ingin mengetahui tingkat kepuasan pelanggan PT. Kereta Api Indonesia di Stasiun Cepu. Metode kuantitatif ini menjelaskan atau menguraikan data yang diperoleh dari lapangan dan dari hasil perhitungan dengan menggunakan Importance and Performance Analysis atau analisis tingkat kepentingan dan kinerja kepuasan pelanggan untuk mengetahui tingkat kepuasan pengguna jasa (Aritonang, 2015). Adapun sasaran penelitian ini adalah mengetahui nilai Customer Satisfaction Indeks (CSI) melalui perhitungan nilai kinerja dan tingkat kepentingan pengguna jasa terhadap pelayanan di Stasiun Cepu dengan metode IPA dan PGCV, mengetahui Indikator pelayanan di Stasiun Cepu yang menjadi prioritas utama (hasil perhitungan IPA \& PGCV) perbaikan dan menghitung kebutuhan dalam Stasiun berdasarkan hasil dari prioritas utama perbaikan fasilitas stasiun agar kinerja lebih optimal berdasarkan Standar Pelayanan Minimum Untuk Angkutan Orang Dengan Kereta Api dan memberikan usulan perbaikan terhadap peningkatan kualitas pelayanan kepada penyedia jasa di Stasiun Cepu.

\subsection{Metode Pengambilan Sampel}

Metode pengambilan sampel adalah langkah dan prosedur yang akan dilakukan dalam pengumpulan data atau informasi guna memecahkan permasalahan. Penelitian ini menggunakan metode pengumpulan data primer dan data sekunder. Data primer antara lain : metode observasi (pengamatan) dan metode kuesioner (angket)/ google form yang telah dibuat . data disebarkan kepada responden yang berada di area Stasiun Cepu dan disebarkan secara online di media sosial. Data sekunder diperoleh melalui data yang diolah dan telah dipublikasikan oleh perusahaan seperti website resmi PT Kereta Api (Persero), data internal perusahaan yaitu Peraturan Direksi PT. Kereta Api Indonesia (Persero) tentang Organisasi dan Tata Laksana Daerah Operasi 4 Semarang, data 
penumpang tiap bulan dan tiap tahun dalam periode 2 tahun terakhir serta berbagai buku, jurnal, skripsi, dan tesis yang berkaitan dengan penelitian.

\subsection{Uji Normalitas}

Uji normalitas bertujuan untuk mengetahui normal atau tidaknya suatu distribusi data. Uji normalitas perlu dilakukan karena data yang berdistribusi normal merupakan syarat dilakukannya parametric test. Data yang normal bisa dianggap dapat mewakili populasi. Pengujian normalitas dengan multivariat dengan melihat nilai standar residualnya sebaran data setiap variabel. Bila nilai standar residualnya berada diantara -2 s.d +2 maka data dapat dikatakan normal (Ghozali, 2011).

\subsection{Uji Validitas}

Validitas mempunyai arti sejauh mana ketepatan dan kecermatan suatu instrumen pengukur (tes) dalam melakukan fungsi ukurnya. Untuk memastikan apakah butir - butir yang ada dalam pernyataan valid atau tidak, maka penelitian ini menggunakan uji validitas. Jika hasilnya valid maka pengolahan data bisa dilanjutkan, tetapi jika hasilnya tidak valid maka proses uji validitas diulang dengan hanya memasukkan pernyataan yang valid saja. Hasil ukur dari pengukuran tersebut merupakan besaran yang mencerminkan secara tepat fakta atau keadaan sesungguhnya dari apa yang diukur.

\subsection{Uji Reliabilitas}

Uji reliabilitas dilakukan untuk mengetahui apakah skala yang dibuat pada kuesioner secara internal sudah konsisten atau tidak. Pengujian konsistensi skala menggunakan uji reliabilitas yang akan memberikan koefisien alfa yang bernilai 0-1, analisis menunjukkan besarnya nilai Cronbach's Alpha $(\alpha)$.

\subsection{Tahapan Penelitian}

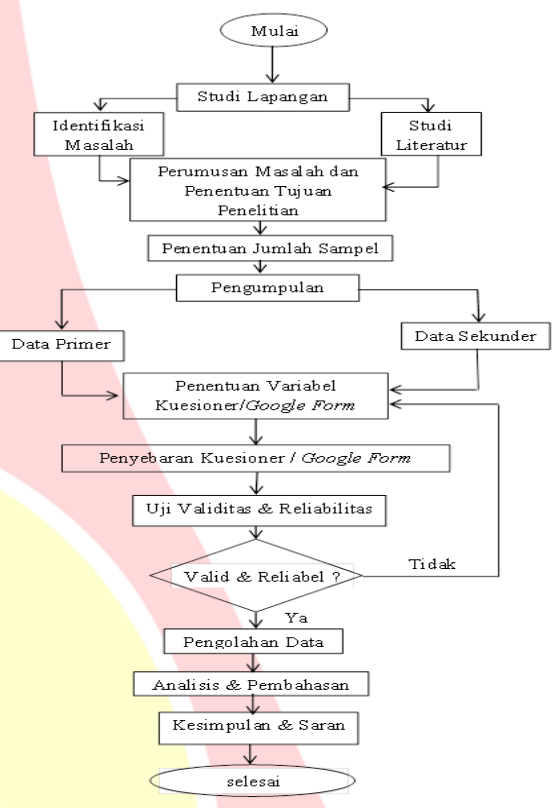

Gambar 1. Tahapan Penelitian

\section{HASIL DAN PEMBAHASAN}

\subsection{Lokasi Penelitian}

Penelitian mengenai Analisis Kepuasan Pengguna Jasa Terhadap Pelayanan PT. Kereta Api Indonesia (Stasiun Cepu) berlokasi di Stasiun Cepu. Penelitian ini dilakukan pada bulan Mei 2021.

Berdasarkan hasil analisis deskriptif dan statistik serta pembahasan dalam penelitian ini, maka dapat diambil kesimpulan sebagai berikut:

Karakteristik responden pengguna jasa di Stasiun Cepu adalah

a. Mayoritas pengguna jasa di Stasiun Cepu berusia $36-45$ tahun dengan persentase 30,3 $\%$ atau sejumlah 40 orang;

b. Proporsi jenis kelamin responden mayoritas pengguna jasa di Stasiun Cepu adalah berjenis kelamin perempuan dengan prosentase $67,4 \%$ atau sejumlah 89 orang;

c. Tingkat pendidikan reponden pada tingkat D3/S1 didapatkan 57,6 \% atau 76 orang;

d. Pekerjaan responden sebagian besar karyawan swasta dengan persentase $25,8 \%$ atau 34 orang;

e. Sebagian besar responden bertujuan untuk berkunjung ke saudara/keluarga dengan persentase $42,2 \%$ atau 56 orang. 


\subsection{Analisis Normalitas}

Uji normalitas bertujuan untuk mengetahui normal atau tidaknya suatu distribusi data. Uji normalitas perlu dilakukan karena data yang berdistribusi normal merupakan syarat dilakukannya parametric test. Data yang normal bisa dianggap dapat mewakili populasi. Pengujian normalitas dengan multivariat dengan melihat nilai standar residualnya sebaran data setiap variabel. Bila nilai standar residualnya berada diantara -2 s.d +2 maka data dapat dikatakan normal. Hasil uji normalitas tertera pada Tabel 3.

Dari distribusi data telah memenuhi syarat normalitas yaitu nilai standar residualnya telah terletak diantara -2 s.d +2 , yaitu $-1,855$ sampai dengan 1,994 .

Tabel 1. Uji Normalitas

\begin{tabular}{|l|r|r|r|r|r|}
\hline & \multicolumn{7}{|c|}{ Resid uals Statistics $^{\mathbf{2}}$} \\
\hline & \multicolumn{1}{|c|}{ Minum } & Maximum & \multicolumn{1}{c|}{ Mean } & Std Deviation & \multicolumn{1}{l|}{ N } \\
\hline Predicted Value & 2.3213 & 4.3856 & 3.5130 & .45518 & 132 \\
Std. Predicted Value & -2.618 & 1.917 & .000 & 1.000 & 132 \\
Standard Error of Predicted & .018 & .052 & .025 & .008 & 132 \\
Value & & & & & \\
Adjusted Predicted Value & 2.3041 & 4.3796 & 3.5130 & .45524 & 132 \\
Residual & -.39336 & .42291 & .00000 & .21126 & 132 \\
Std. Resid ual & $-\mathbf{1 . 8 5 5}$ & $\mathbf{1 . 9 9 4}$ &. $\mathbf{0 0 0}$ & .996 & $\mathbf{1 3 2}$ \\
Stud. Residual & -1.862 & 2.003 & .000 & 1.004 & 132 \\
Deleted Residual & -.39657 & .42651 & .00004 & .21455 & 132 \\
Stud. Deleted Residual & -1.880 & 2.026 & .000 & 1.008 & 132 \\
Mahal. Distance & .000 & 6.855 & .992 & 1.381 & 132 \\
Cook's Distance & .000 & .073 & .008 & .011 & 132 \\
Centered Leverage Value & .000 & .052 & .008 & .011 & 132 \\
\hline
\end{tabular}

\subsection{Uji Validitas}

Analisis validasi adalah untuk menguji keabsahan kuesioner. Analisis bisa dilanjutkan jika kuesioner telah dinyatakan valid. Penelitian ini menggunakan instrumen berupa penyampaian kuesioner kepada seluruh responden yang terdiri dari kepentingan dan kinerja sebanyak 27 pertanyaan. Instrumen dinyatakan valid apabila item yang mempunyai korelasi positif dengan total skor serta korelasi tinggi, menunjukkan bahwa item tersebut mempunyai validitas yang tinggi pula. Persyaratan minimum agar dapat dianggap valid apabila nilai $r$ hitung $>$ nilai kritis ( $r$ tabel) pada $\alpha=0,05$. Dengan menggunakan jumlah responden sebanyak 132 maka nilai $r$ tabel dapat diperoleh melalui tabel $r$ product moment pearson dengan df (degree of freedom $)=\mathrm{n}-\mathrm{k}$, jadi $\mathrm{df}=132-2=130$, maka $\mathrm{r}$ tabel $=0,140$ (Affandi, 2018). Berdasarkan uji validitas terlihat bahwa koefisien korelasi antara skor butir dan skor total semuanya diatas 0,140 sehingga dapat dikatakan bahwa semua butir jawaban pertanyaan yang digunakan dalam kuesioner penelitian adalah valid.

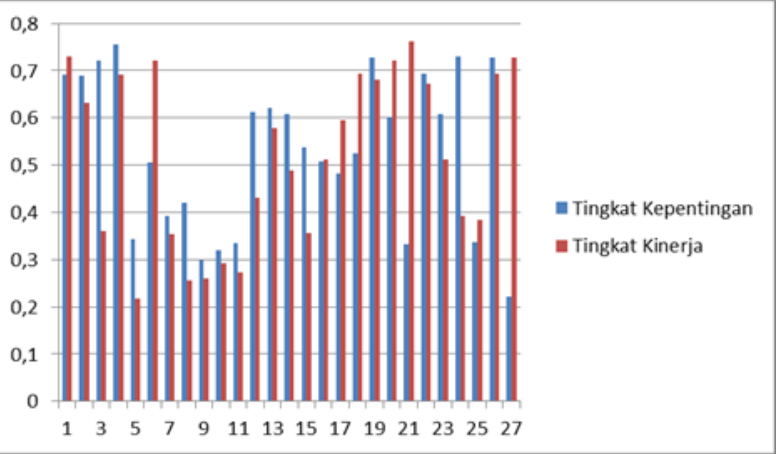

Gambar 2. Grafik Uji Validitas

\subsection{Uji Reliabilitas}

Uji reliabilitas dilakukan untuk mengetahui sejauh mana hasil pengukuran handal (reliabel) bila pengukuran dilakukan berulang-ulang. Teknik uji reliabilitas dengan menggunakan koefisien alpha cronbach, dengan taraf nyata 5\%, hal ini perhitungannya juga menggunakan bantuan program komputer SPSS versi 22. Dengan kriteria jika koefisien korelasi lebih besar dari nilai kritis atau apabila nilai alpha cronbach $>0,600$, maka item tersebut dinyatakan reliabel (Ghozali, 2009). Berdasarkan uji reliabilitas yang tertuang pada Tabel 5, terlihat bahwa cronbach's alpha jauh lebih besar dari nilai kritis $=0,600$ pada $\alpha=0,05$. Dengan demikian instrumen penelitian yang digunakan pada variabel kualitas pelayanan dapat dinyatakan reliabel dan benar-benar sebagai alat ukur yang handal dan memiliki tingkat kestabilan tinggi, dalam arti alat ukur tersebut apabila dilakukan secara berulang, hasil dari pengujian instrumen tersebut akan menunjukkan hasil yang tetap. Hasil uji reliabilitas jawaban responden yang terdiri dari 27 item pertanyaan sebagaimana tertera pada tabel 5 .

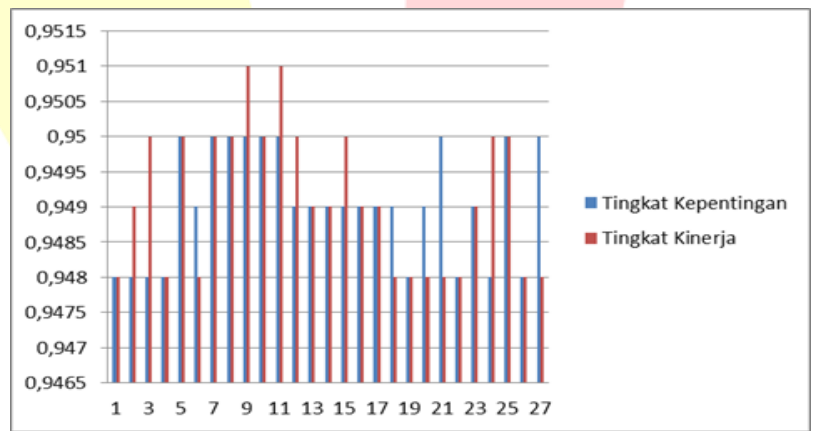

Gambar 3. Grafik Uji Reliabilitas

\subsection{Metode CSI}

Hasil perhitungan CSI didapat nilai $74 \%$ yang mengindikasikan tingkat kepuasan pengguna jasa terpenuhi terhadap pelayanan di Stasiun Cepu 
termasuk dalam kategori puas. Hasil perhitungan indeks kepuasan pengguna jasa dapat dilihat pada Tabel 2

\section{Tabel 2. Perhitungan CSI}

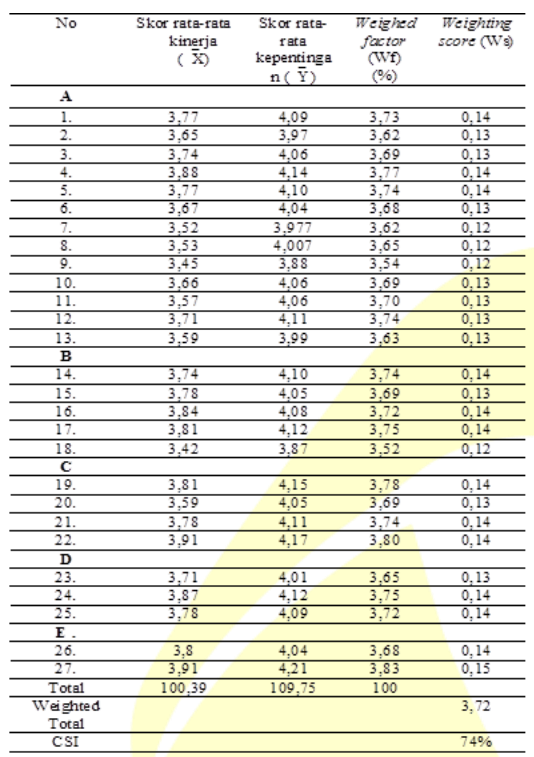

\subsection{Metode IPA}

Hasil perhitungan nilai $\mathrm{X}$ (rata-rata skor tingkat kepuasan) dan $Y$ (rata-rata skor tingkat kepentingan) kemudian dipetakan dalam diagram kartesius, yang bertujuan untuk mengetahui letak atribut terdapat pada kuadran berapa. Pengukuran tingkat kesesuaian dilakukan untuk mencari urutan prioritas perbaikan layanan.

Hasil dari tingkat-tingkat unsur yang mempengaruhi kepuasan pengguna jasa akan dijabarkan dan dibagi menjadi empat kuadran kedalam diagram kartesius.

\section{Kuadran I (Prioritas Utama)}

Wilayah yang memuat item-item dengan tingkat kepentingan yang relatif tinggi dengan tingkat kinerja yang rendah, sehingga kenyataanya belum sesuai dengan harapan pengguna. Item-item yang termasuk dalam kuadran ini harus segera ditingkatkan kinerjanya. Atribut yang berada pada kuadran ini ada 2 atribut yaitu kuadran ke 11 dan 12 (kebersihan dan kenyamanan toilet).

\section{Kuadran II (Pertahankan Prestasi)}

Wilayah yang memuat item-item yang memiliki tingkat kepentingan relatif tinggi dengan tingkat kepuasan yang relatif tinggi pula. Item yang termasuk dalam kuadran ini dianggap sebagai faktor penunjang bagi kepuasan pengguna jasa sehingga harus tetap dipertahankan karena semua item ini menjadikan produk atau jasa tersebut unggul di mata pengguna, atribut yang berada pada kuadran ini antara lain atribut ke 1, 4, 5, 14, 16, 17, 19, 21, $22,24,25,27$.

\section{Kuadran III (Prioritas Rendah)}

Wilayah ini memuat item-item dengan tingkat kepentingan yang relatif rendah dan kenyataan kinerjanya tidak terlalu istimewa dengan tingkat kepuasan yang relatif rendah. Item yang termasuk dalam kuadran ini memberikan pengaruh yang sangat kecil terhadap manfaat yang dirasakan oleh pengguna, atribut yang berada pada kuadran ini antara lain atribut ke 2, 6, 7, 8, 9, 10, 13, 18, 20.

\section{Kuadran IV (Berlebihan)}

Item-item yang dimuat dalam wilayah kuadran ini yaitu dengan tingkat kepentingan yang relatif rendah dan dirasakan oleh pengguna terlalu berlebihan dengan tingkat kepuasan yang relatif tinggi. Biaya yang digunakan untuk menunjang item yang masuk ke dalam kuadran ini dapat dikurangi untuk menghemat biaya pengeluaran, atribut yang berada pada kuadran ini antara lain atribut ke 3, 15, 23,26.

\section{Gambar 4. Matriks IPA}

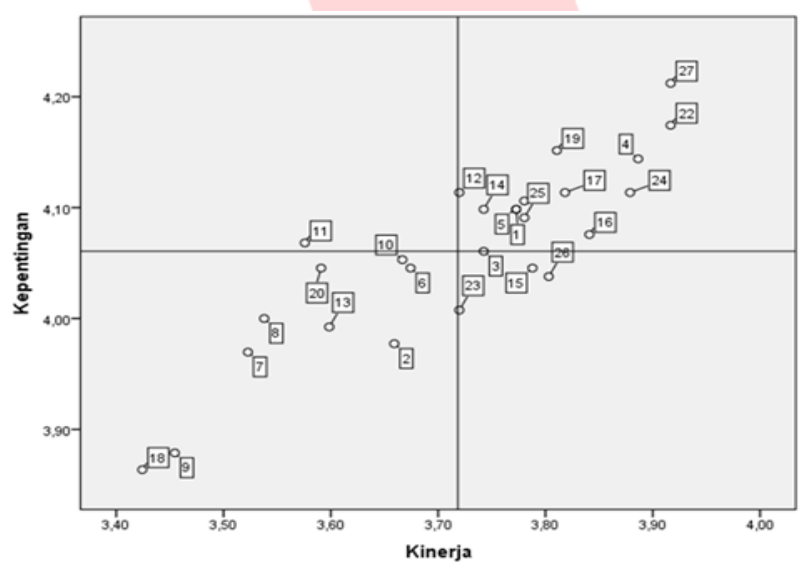

\subsection{Analisis Indeks Potential Gain Customer Value (PGCV)}

Data terlebih dahulu dikonversi dengan menggunakan metode successive interval dan atribut yang diprioritaskan merupakan atribut yang memiliki nilai indeks PGCV diatas rata-rata, kemudian baru atribut yang berada dibawah ratarata (Budiarto, 2001). Kriteria penilaian yang menjadi prioritas untuk ditingkatkan kualitas layanannya akan ditentukan berdasarkan dari 2 kuadran di IPA kuadran I dan kuadran III yaitu. Dari 
masing-masing kuadran tersebut dianalisis sesuai dengan prioritas berdasarkan hasil perhitungan nilai PGCV. Pada kuadran I terdapat dua indikator yaitu atribut ke 12 (kebersihan stasiun) dan atribut ke 11 (kebersihan dan kenyamanan toilet) yang termasuk prioritas utama untuk ditingkatkan pelayanannya. Kriteria penilaian yang menjadi prioritas selanjutnya (kuadran III) dapat dilihat pada tabel 3.

Tabel 3. Perhitungan PGCV

\begin{tabular}{|c|c|c|c|c|c|c|c|c|}
\hline Kuadran & $\begin{array}{l}\text { Indik } \\
\text { ator }\end{array}$ & $P$ & I & $\mathrm{ACV}$ & Ps & UDCV & $\mathrm{PGCV}^{-}$ & $\begin{array}{l}\text { Pri } \\
\text { ori } \\
\text { tas }\end{array}$ \\
\hline \multirow[b]{2}{*}{ I } & 12 & 3,75 & 3,17 & 11,93 & 5 & 15,88 & 3,94 & 1 \\
\hline & 11 & 3,75 & 3,102 & 11,65 & 5 & 15,51 & 3,85 & 2 \\
\hline \multirow{9}{*}{ III } & 2 & 2,83 & 3,75 & 10,67 & 5 & 18,78 & 8,11 & 3 \\
\hline & 18 & 3,17 & 3,75 & 11,93 & 5 & 18,78 & 6,85 & 4 \\
\hline & 7 & 3,10 & 3,52 & 10,92 & 5 & 17,60 & 6,68 & 5 \\
\hline & 9 & 3,26 & 3,75 & 12.26 & 5 & 18,78 & 6,52 & 6 \\
\hline & 20 & 3,26 & 3,17 & 10,36 & 5 & 15,88 & 5,51 & 7 \\
\hline & 13 & 3.37 & 3,10 & 10,46 & 5 & 15,51 & 5,04 & 8 \\
\hline & 8 & 3,37 & 3,03 & 10,24 & 5 & 15,19 & 4,94 & 9 \\
\hline & 6 & 3,52 & 3,03 & 10,69 & 5 & 15,19 & 4,49 & 10 \\
\hline & 10 & 3,75 & 3,26 & 12.26 & 5 & 16,32 & 4,05 & 11 \\
\hline
\end{tabular}

\section{KESIMPULAN DAN SARAN}

\subsection{Kesimpulan}

Berdasarkan hasil analisis deskriptif dan statistik serta pembahasan dalam penelitian ini, maka dapat diambil kesimpulan sebagai berikut:

1. Karakteristik responden pengguna jasa di Stasiun Cepu adalah mayoritas pengguna jasa di Stasiun Cepu berusia 36 - 45 tahun dengan persentase $30,3 \%$ atau sejumlah 40 orang; Proporsi jenis kelamin responden mayoritas pengguna jasa di Stasiun Cepu adalah berjenis kelamin perempuan dengan prosentase 67,4\% atau sejumlah 89 orang; Tingkat pendidikan reponden pada tingkat $\mathrm{D} 3 / \mathrm{S} 1$ didapatkan $57,6 \%$ atau 76 orang; Pekerjaan responden sebagian besar karyawan swasta dengan persentase 25,8 $\%$ atau 34 orang; Sebagian besar responden bertujuan untuk berkunjung ke saudara/keluarga dengan persentase $42,2 \%$ atau 56 orang..

2. Nilai customer satisfaction indeks (CSI) stasiun Cepu. Berdasarkan indeks kepuasan, nilai Costumer Satisfaction Index (CSI) sebesar 74\% berada pada rentang $66 \%-80 \%$ yang berarti, secara umum indeks kepuasan pengguna jasa Stasiun Cepu berada pada kriteria "Puas".

3. Kualitas pelayanan dengan menggunakan metode IPA (Important Performance Analisis). Kuadran I terdapat 2 atribut yang harus segera diperbaiki yaitu atribut ke 12 kebersihan stasiun dan ke 11 kebersihan dan kenyamanan toilet
Stasiun Cepu. Pada sebuah stasiun kebersihan stasiun, kebersihan dan kenyamanan toilet seharusnya menjadi sesuatu yang tidak dapat diabaikan.

4. Kualitas layanan jasa pada PT. KAI di Stasiun Cepu menggunakan metode IPA dan PGCV (potential gain customer value) dengan urutan prioritas perbaikan (yang harus diperbaiki terlebih dahulu):

a. Kebersihan stasiun;

b. Kebersihan dan kenyamanan toilet;

c. Ketersediaan informasi dan fasilitas kesehatan/ pos kesehatan (obat-obatan, kursi roda, tandu);

d. Tersedianya informasi angkutan lanjutan/integrasi transportasi lain;

e. Ketersediaan dan kenyamanan area parkir;

$f$. Tersedia ruang ibu menyusui (nursery room);

g. Tersedia loket tiket manual dan/atau vending machine;

h. Tersedianya tempat sampah (organik dan anorganik);

i. Tersedia fasilitas khusus yang disediakan untuk penumpang yang berkebutuhan khusus (kursi, jalur kursi roda);

j. Ketersediaan area untuk penumpang/ petugas berkumpul apabila terjadi keadaan darurat;

k. Ketersediaan dan kenyamanan ruang tunggu penumpang (terdapat kursi prioritas).

\section{Rekomendasi usulan perbaikan}

Atribut 12 kebersihan stasiun lebih ditingkatkan berdasarkan pengamatan kurangnya tempat sampah di area peron dan ruang tunggu stasiun, sehingga banyak sampah di area tersebut. Penambahan jumlah tempat sampah dan petugas kebersihan diharapkan dapat menjadi jalan keluar untuk permasalahan tersebut..

Atribut 11 meningkatkan pelayanan kebersihan dan kenyamanan di toilet. Berdasarkan pengamatan, toilet terdapat kerak berwarna coklat di dinding, wastatafel dan closet. Pembersihan toilet lebih diperhatikan dan ditingkatkan agar toilet selalu bersih dan nyaman sehingga pengguna jasa merasa nyaman saat menggunakan toilet.

\subsection{Saran}

Dari hasil yang diperoleh dari penelitian tentang kualitas pelayanan terhadap tingkat kepuasan pengguna jasa kereta api di Stasiun Cepu, maka disarankan sebagai berikut: 
Saran yang dapat dikemukakan dari penelitian ini supaya masalah-masalah yang ditemukan berdasarkan metode IPA terdapat pada kuadran I (atribut ke 12 dan ke 11) dan Potential Gain Customer Value (PGCV) di atas agar diselesaikan secepatnya. Indikator di kuadran IV adalah indikator yang dirasa berlebihan sehingga perlu pengurangan pelayanan pada indikator di kuadran IV yang terdiri dari atribut ke 3, 15, 23, 26.

\section{UCAPAN TERIMAKASIH}

Ucapan terimakasih kami sampaikan kepada Bapak Prof. Ir. Sigit Priyanto, M.Sc.,Ph.D dan Bapak Imam Muthohar, S.T., M.T., D.Eng selaku dosen pembimbing dan seluruh tenaga pengajar serta akademik.

\section{REFERENSI}

Aritonang, R. (2005). Kepuasan Pelanggan. Jakarta: Gramedia.

Astuti, H. (2007). Analisis Kepuasan Konsumen (Servqual Model dan Important Performance Analysis Model). Journal Article Media Ekonomi Universitas Muhammadiyah Purwokerto.

Eurobarometer, F. (2013). Europeans" Stisfaction with Rail Services" The European Commision, Directorate-Generale Mobility and Transport. Directorat-General Mobility and Transport.

Fornell, C. J. (1996). The American Customer Satisfaction Index: Nature, Purpose, and Finding. Journal of Marketing, 7-18.

Gasperz, Z. (1997). Manajemen Kualitas Dalam Industri Jasa. Jakarta: Gramedia.

Ghozali, I. (2011). Aplikasi Analisis Multivariate Dengan Program SPSS. Semarang: Universitas Diponegoro.

Heiscmidt, K. M. (2013). Importance-performance analysis revisited : the role ofthe factor structure of customer satisfaction. The Service Industries Journal, 112-129.

Hom, W. (1997). Make Customer Service Analysis A Little Easier With The PGCV Index. Quality Progress; Proquest, 89-97.
Indonesia, U. U. (2007). Undang-Undang Republik Indonesia Nomor 23 Tahun 2007 tentang Perkeretaapian .

Iriani, N. (2018). Importance of Performance Analysis and Potential Gain in Customer Value's of Service Quality in Hospitals. Advances in Sosial Science, Education and Humanities Research, 503507.

James, J. (1977). Importance Performance Analysis. Jurnal Of Marketing, 77-79.

Kemenhub. (2019). Peraturan Menteri Perhubungan RI No. PM 63 tahun 2019 Tentang Standar Pelayanan Minimum Angkutan Orang dengan Kereta Api. Menteri Perhubungan RI.

Kemenkes. (2020, Januari 1). Retrieved from http://www.kemkes.go.id/folder/view/fullcontent/structure-faq.html

Keputusan Menpan Nomor 63 Tahun 2003.

Keputusan Menteri Pendayagunaan Aparatur Negara (Menpan) Nomor 63 Tahun 2004 tentang Pedoman Umum Penyelenggaraan Pelayanan Publik.

Surat Edaran Nomor : SE 14 Tahun 2020 Tentang Pedoman dan Petunjuk Teknis Pengendalian Transportasi Perkeretaapian dalam Masa Adaptasi Kebiasaan Baru Untuk Mencegah Penyebaran Corona Virus Disease 2019.

Tjiptono. (1998). Manajemen Jasa. Yogyakarta: Andi Offset.

Umar, H. (1998). Metode Penelitian untuk Skripsi dan Tesis Bisnis . Jakarta: PT. Raja Grafindo Persada.

Wahyu Adinda Febriana Firdaus, G. N. (2020). The Impact Of Covid-19 Pandemic to The Quality Of Service And Customer Satisfaction On The Performance Of Indonesia Railways Company (PT. Kereta Api Indonesia). GROSTLOG 2020, 296-301. 